\title{
MODERN MANAGEMENT AND MARKETING OF THE FASHION INDUSTRY USING THE BRAND EXAMPLE OF YVES SAINT LAURENT.
}

\author{
Anastazja Magdalena Kasztalska ${ }^{1}$
}

\begin{abstract}
The Brand Yves Saint Laurent is a company that represents a modern approach to management in the fashion industry. This article aims to answer the question of whether modern methods of marketing and management to generate profits for the company in the form of greater customer interest and increased sales. Research methods used in the article is a survey made with the cooperation with the buyers of luxury brand Yves Saint Laurent. Unquestionably, there is a strong link between marketing luxury brands and its results in sales. Further research can be focused on a bigger scale of this huge phenomenon.
\end{abstract}

UDC Classification: 005.3, 33; DOI: http://dx.doi.org/10.12955/cbup.v5.929

Keywords: Fashion, Industry, Luxury, Yves Saint Laurent, Management, Marketing.

\section{Yves Saint Laurent Brand}

The YSL (also known as Saint Laurent Paris) is a luxury fashion house founded by Yves Saint Laurent and his partner Pierre Bergé. The name founder of the brand, Yves Saint Laurent, died in 2008, while the fashion house produced its last line of haute couture in 2002.

The brand was founded in 1961 and is considered one of the most recognizable in the world. It known for its modern and very trendy designs, such as based on tuxedo jacket for women. Currently, YSL offers a wide range of models of clothes, leather goods, footwear and jewelry, while having large market shares in the cosmetic industry, amongst others, from the sale of perfumes. The current brand logo was designed in 1963 by A.M. Cassandre (Mouron, 1986).

In the $60 \mathrm{~s}$ and $70 \mathrm{~s}$ the firm popularized fashion trends such as a rebellious look, dress in safari style, very tight trousers for both women and men, adjacent and high boots (knee) and most famously its project tuxedo for women - Le Smoking Suit in 1966 (Drake, 2006). Some of the most memorable collections include inspiration from the Russian ballet, Pop Art, Picasso and the Far East among the muses and inspirations of Saint Laurent were Loulou de la Falaise (the daughter of a French marquis), Betty Catroux (English-Irish model), Talitha Pol Getty (the daughter of an American diplomat) and Catherine Deneuve - famous French actress. Brand ambassador in the 70s and early 80s was London millionaire Diane Vandelli (Née Princess Romanovsky), making the brand became increasingly popular among the European elite (Borrelli-Persson, 2017). The company YSL continues to grow with the introduction of a line of fragrances for men and women, that started a line in 1978. However, its share price began to fall after i. In 1993, Saint Laurent fashion house was sold to a pharmaceutical company Sanofi and Pierre Bergé appointed Hedi Slimane as an artistic director in 1997, who along with it resumed YSL Rive Gauche Homme. Hedi Slimane decided to leave the fashion house two years later and was the general manager of the sewing luxury men's suits - Ermenegildo Zegna (Porter, 2016).

In the 1999 Gucci bought the YSL brand and referred the proposal to Tom Ford who designed the casual collection, while Saint Laurent designed the haute couture collection. Saint Laurent did not hide his disapproval of Tom Ford during their collaboration, it is still criticized and publicly ridiculed. In 2002 Saint Laurent closed the production of haute couture fashion house YSL, due to his poor health, drug and alcohol addiction, severe depression and ever sharper criticism of his projects. The creator of the brand often said "Chanel liberated women, and I gave them the strength ", he also claimed that he "created the contemporary woman's wardrobe" (Rawsthorn, 1996). Tom Ford left the fashion house in 2004, and was replaced by Stefano Pilati, whose designs were much more French than the emanating erotic visions of Ford. In 2009 after the death of Yves Saint Laurent and a few turbulent years of design by Stefano Pilati, some key boutiques of YSL were closed in San Francisco and New York. It was also announced that the design studio will have its headquarters in Los Angeles, California. In 2012 KERING Group announced that Hedi Slimane will replace Stefano Pilati as Creative Director. Slimane previously designed for Dior until 2007 (Cowles, 2012). Unfortunately, Hedi Slimane left YSL brand on $31^{\text {th }}$ March 2016 his replacement is Anthony Vaccarello (Socha, 2016).

\footnotetext{
${ }^{1}$ Faculty of Management, University of Economics, Katowice, anastazja.kasztalska@gmail.com
} 


\section{Management and Marketing of the Yves Saint Laurent brand}

The reinstatement of people who manage the company well and make the necessary innovation helped the brand very much. Hedi Slimane has worked previously for YSL, his return had raised a lot of controversy, especially after the announcement of the new collection and switch of brand names to "Saint Laurent" instead of the full Yves Saint Laurent or YSL. However, the name Yves Saint Laurent and the YSL initials still remain on accessories such as handbags and shoes, and cosmetics like perfumes (Winckel, 2013).

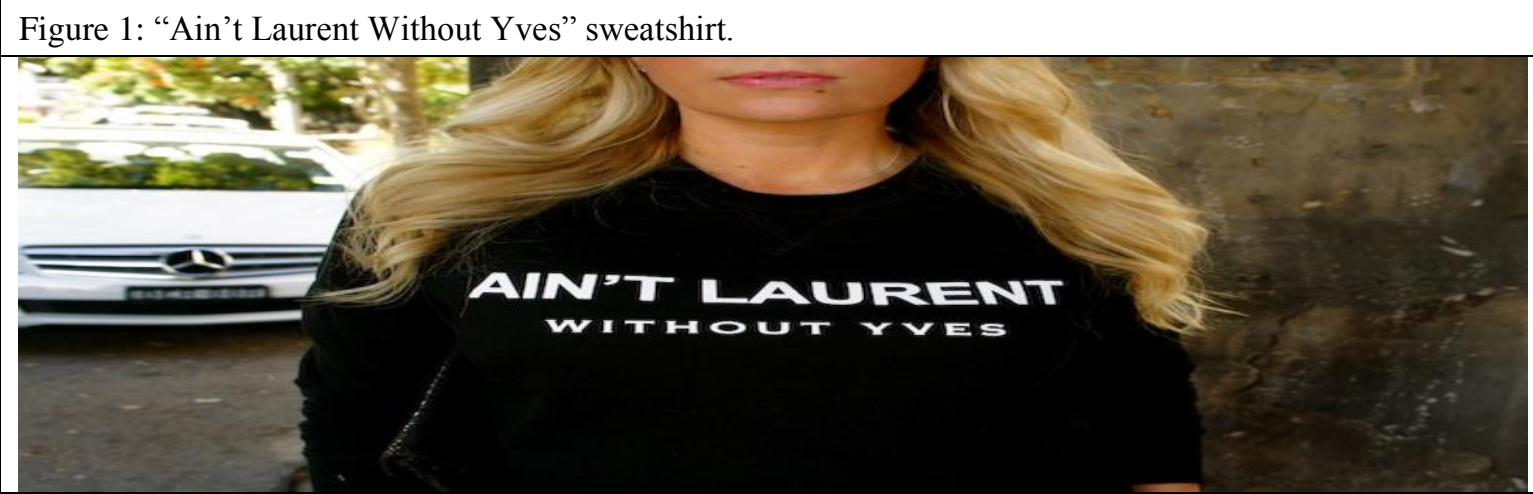

Source: Authors

The suspension of cooperation with a sales partner like Parisian boutique Colette, destroyed the image of the brand. Decisions by Hedi Slimane circulated worldwide and accounted for the largest newspaper headlines devoted to the fashion industry. These decisions became even more controversial when famous Parisian boutique Colette, started selling shirts with the inscription 'Is not Laurent Without Yves ". The YSL company asked the store to stop selling the shirts, and when that did not work, on the October 2013 Colette received a letter accusing them of the sale of counterfeit goods, which however instead seriously damaged the reputation of the brand itself. Then Saint Laurent announced that it will not execute orders for the new Spring 2014 collection for the boutique Colette, despite the fact that the store has sold collections from YSL since 1998 (Sowray, 2013).

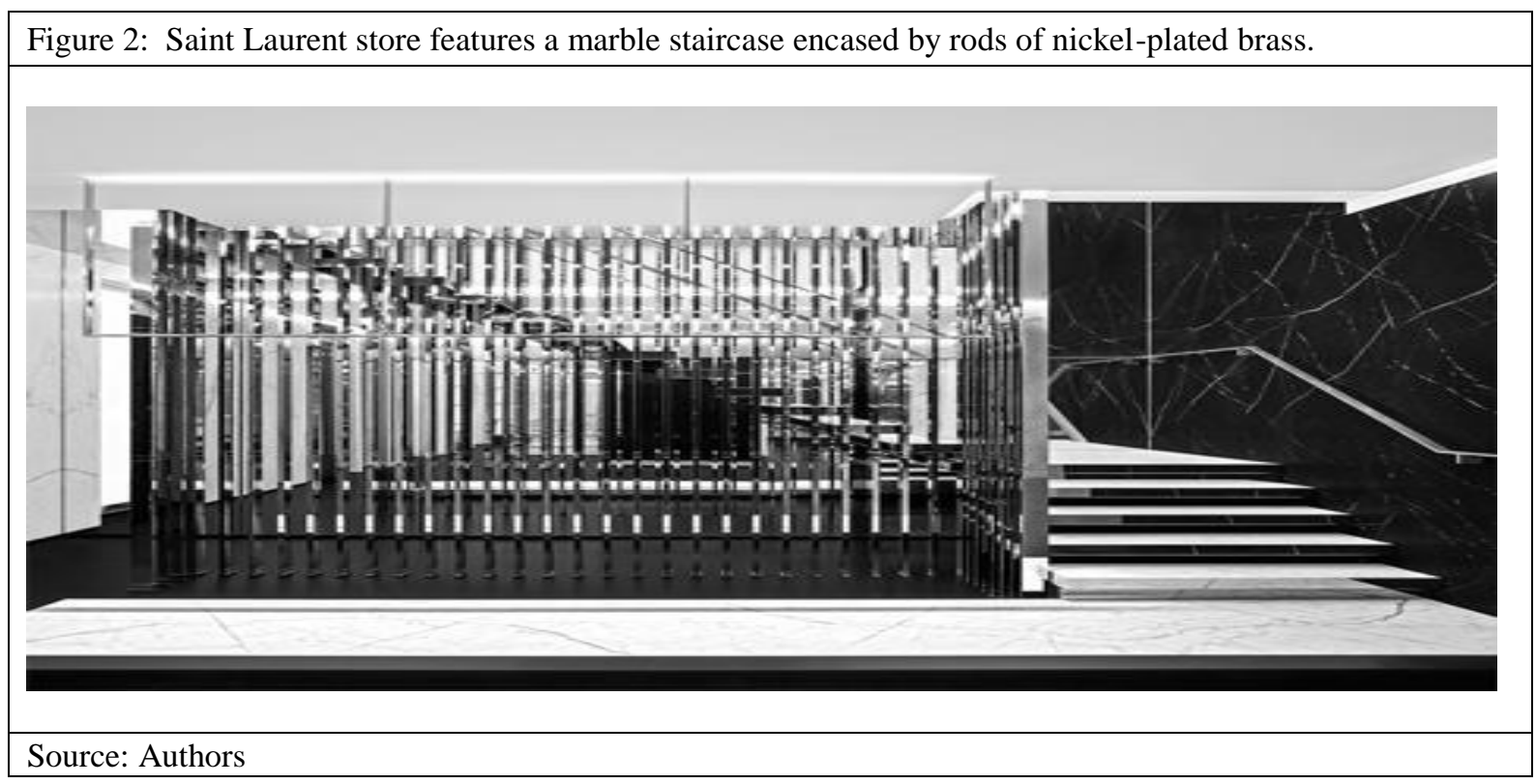

\section{The modern interior design shops improves the brand}

Slimane designed the brand's flagship boutique in Paris which opened in 2013. The colors of deep red and gold, were replaced by a monochrome interior (mainly in shades of gray), created from various materials, including marble and nickel rods. This concept of interior design was also used in the boutique in Beverly Hills, the newly opened boutique in London and several new stores in the United States. Slimane officially plans to continue to develop a network of YSL boutiques in the United 
States, opening new stores with monochrome décor in the resort of Bal Harbour, Florida, and in Washington DC (Chalcraft, 2013).

\section{Choosing the right store locations}

Locations are the international points of sale and instill a strong brand in Europe as they are in key cities, such as Barcelona, Munich, Berlin, Warsaw, Kiev, Rome, Moscow and Cannes. Locations in the Middle East and in Africa are Casablanca, Abu Dhabi, Beirut and Jeddah. Asian YSL boutiques are Jakarta, Bangkok, Seoul, Macau and Hong Kong. The company strongly marked its presence in Japan by opening stores in Kyoto, Tokyo and Osaka, and many brand outlets located throughout the country. In China, individual boutiques are located in Wuhan, Shanghai and Beijing. Saint Laurent brand can also be found in many upscale stores worldwide (Official Yves Saint Laurent page, Retrieved: 27.02.2016).

\section{Methodology}

The survey is focused on selecting by interviewer, persons that represent interesting and tested qualities. The survey omits persons that do not have features which are being studied. An example is the study of the phenomenon of the luxury fashion industry, while respondents are the only owners of the items with label YSL or observers of the brand or the supporters of this company who have a certain opinion about this market. Individuals who for various reasons are not interested in luxury fashion industry, were excluded from the study because they do not have the relevant experience and a clear opinion about the exclusive fashion designers and luxury fashion brands (Lynn, 2014).

The survey was sent by email to people who are actively participating in the life of luxury fashion industry, as well as fans of the YSL brand. In the survey, 130 people participated. The survey was conducted in December 2016 and January 2017. Respondents had a very high degree of freedom of expression, because they could modify the questions and add their own observations and comments. Subjects were men and women, diverse in age, as the youngest tested person was 19 years old and the oldest 84. Age and gender had little significance as a major determinant. The main factor was the wealth of a person who can afford to be an owner of luxury clothes for example the items made by YSL brand.

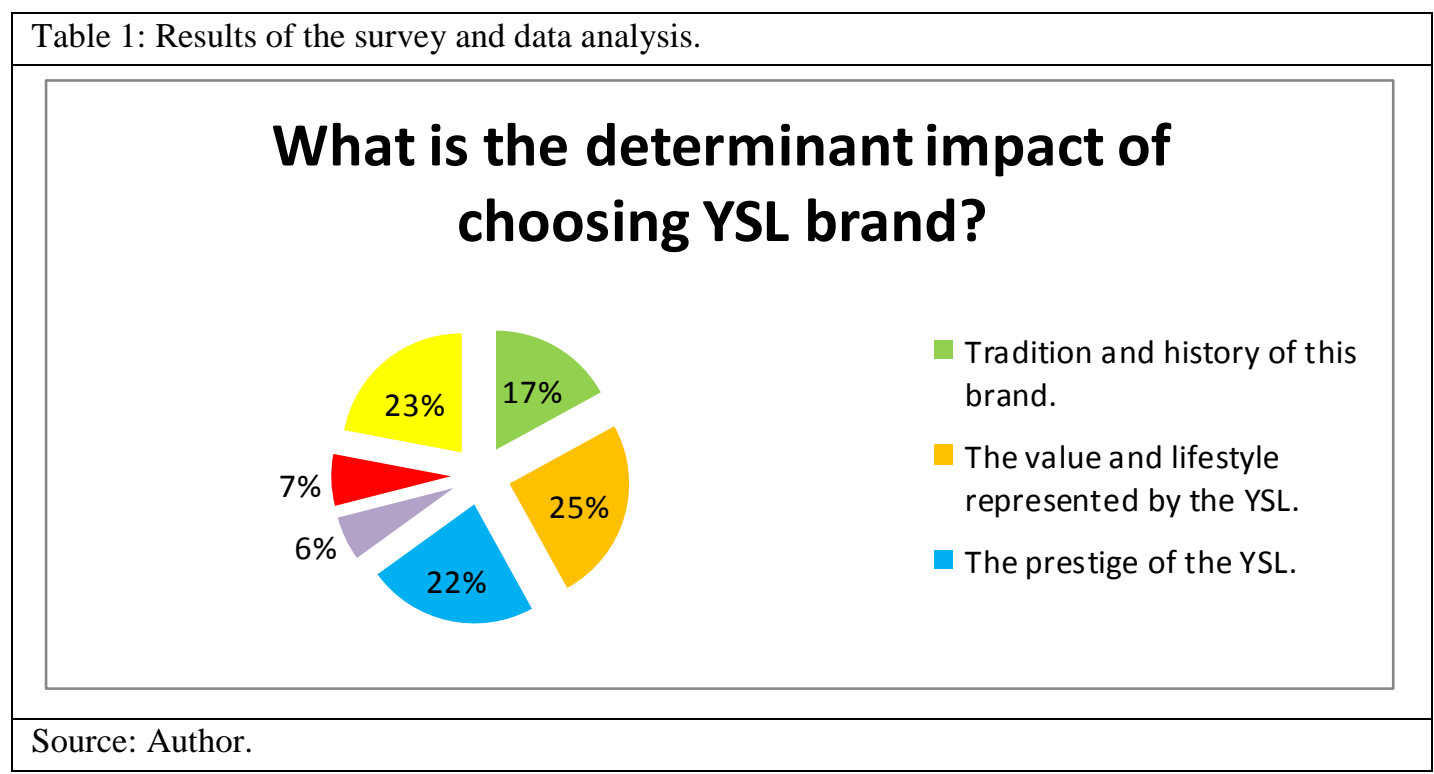

Most respondents indicated the value and lifestyle represented by the brand YSL (25\%), this may be associated with the ideas that managers of the brand believe and many people can identify with. Another very large group is a group of people who decided to buy luxury clothes made by YSL because of the convenient localization and interior of the shops $(23 \%)$. Respondents indicated that a major determinant was when they travel and want to relax, they visit places that are suitable for their expectations of the interior of a shop. Another group almost as large as the previous two is a group of people who buy items made by YSL because of the prestige of this brand (22\%). It can be connected with the caring of the brand of its image, which is almost perfect. Some people were owners of the 
luxury clothes made by YSL because they appreciate the tradition and the history of this company (17 $\%)$. It is affected by the long and very interesting history of this brand and also the tradition that started many years ago and is still alive and in practice. Few people decided that the most important factor for them was the unique design of clothes (7\%). It can be the result of the very classical style of the YSL, that has not changed a lot over the years. Customers buy products of this company not because of the influence of the fashion but for the company that is well known and very respected in the fashion industry. The smallest group were those who choose YSL because of its quality of products $(6 \%)$. These customers prefer the quality of the product rather than the history of the brand, that for them doesn't have any significant influence during making the decision of a purchase.

\section{Conclusion}

With a doubt, marketing of luxury brands can significantly increase a company's revenue. Marketing of luxury brands significantly increases the demand for them. This is because for the customers the most important factor is the prestige of a luxury brand, which is created by the marketing of a company. Another factor is the value and lifestyle represented by the brand, which is also created by the appropriate marketing for a specific group of customers.

Managers through proper sales techniques can enhance the prestige of the brand, because for the respondents the most important features of the luxury brand are the features that company can create freely by the proper sales techniques. The need to express one's character by the purchase of luxury goods demonstrates the ability to customize brand products to the tastes and preferences of the target customers. Creating a person of the founder or the brand's chief designer significantly increases the prestige of the brand, because it makes the brand it in the eyes of customers more exclusive and luxurious. Managers can effectively create prestige luxury brands through the appropriate sales techniques based on emphasizing the nature of the purchaser by the company's products, the creation of the legend of the charismatic founder or designer and by controlling the image of the brand buyer in the eyes of themselves, and in the eyes of other people.

\section{References}

Borrelli-Persson L. (2017) Who Inspired Yves Saint Laurent? A Look Back at the Designer's Favorite Muses, Vogue, 01.03.2017.

Chalcraft E. (2013). Saint Laurent opens new flagship store in Paris, Dezeen Magazine, 15.05.2013.

Chalcraft E., Saint Laurent opens new flagship store in Paris (2013, May 15) Retrieved from:

Colo N., Ain't Laurent (2013, February 17) Retrieved from:

Cowles Ch. (2012). YSL Confirms Hedi Slimane's Return, New York Times, 07.03.2012.

Drake A. (2006) The Beautiful Fall: Lagerfeld, Saint Laurent, and Glorious Excess in 1970s Paris, Brown and Company, p.49.

http://fashionhound.tv/aint-laurent-2/

https://www.dezeen.com/2013/05/15/hedi-slimane-opens-saint-laurent-flagship-store-in-paris/

Lynn P. (2014) Longer interviews may not affect subsequent survey participation propensity. Public Opinion Quarterly, № 78 (2), p. 500.

Mouron H. (1986) Cassandre : Posters, Typography, Stage Designs. London: Thames and Hudson. p. 147-148.

Official Yves Saint Web Page: http://www.ysl.com/corporate/en/saint-laurent-store-locator/, Retrieved: 27.02.2017.

Porter C. (2016). Can this man save the suit? Retrieved 25.02.2017 from

https://search.proquest.com/docview/1847598268?accountid=45580

Rawsthorn A. (1996). Yves Saint Laurent - A Biography. Nan A. Talese/Doubleday.

Socha M. (2016). Saint Laurent Confirms Hedi Slimane Exit, WWD Fashion, 01.04.2016.

Sowray B. (2013). Saint Laurent withdraw from Colette over parody T-shirt, The Telegraph UK, 01.10.2013.

Winckel E. (2013). Hardly a black-and-white matter: Analyzing the validity and protection of single-color trademarks within the fashion industry. Vanderbilt Law Review, 66(3), p. 1015-1052. 